\title{
CORRIGENDUM
}

\section{Pilot surveillance for childhood encephalitis in Australia using the Paediatric Active Enhanced Disease Surveillance (PAEDS) network - CORRIGENDUM}

P. N. BRITTON, R. C. DALE, E. ELLIOTT, M. FESTA, K. MACARTNEY,

R. BOOY AND C. A. JONES

doi:http://dx.doi.org/10.1017/S0950268816000340 Published online: 26 February 2016.

In the above-mentioned article [1] an error was made in the Acknowledgements section. 'Norah Therese-Hayes' should read

'Norah Therese Hayes-Ratcliffe'. The authors apologize for this error.

\section{REFERENCE}

1. Britton PN, Dale RC, Elliott E, Festa M, Macartney K, Booy R, Jones CA. Pilot surveillance for childhood encephalitis in Australia using the Paediatric Active Enhanced Disease Surveillance (PAEDS) network. Epidemiology and Infection. doi:10.1017/S0950268816000340. Published online: 26 February 2016. 